\title{
Detection and Molecular Characterization of Resistance to the Dicarboximide and Benzamide Fungicides in Botrytis cinerea From Tomato in Hubei Province, China
}

\author{
M. Adnan, Key Lab of Horticultural Plant Biology, Ministry of Education, and College of Plant Science and Technology, Huazhong Agricul- \\ tural University, Wuhan 430070, China; M. S. Hamada, Key Lab of Horticultural Plant Biology, Ministry of Education, and College of Plant \\ Science and Technology, Huazhong Agricultural University; and Pesticides Department, Faculty of Agriculture, Mansoura University, Man- \\ soura 35516, Egypt; G. Q. Li, College of Plant Science and Technology and the Key Lab of Crop Disease Monitoring \& Safety Control in \\ Hubei Province, Huazhong Agricultural University; and C. X. Luo, ${ }^{\dagger}$ Key Lab of Horticultural Plant Biology, Ministry of Education, and Col- \\ lege of Plant Science and Technology, Huazhong Agricultural University
}

\begin{abstract}
Altogether, 192 Botrytis cinerea isolates collected from tomato greenhouses at different locations in Hubei Province were evaluated for their sensitivity to fungicides procymidone and zoxamide. The mean effective concentration to cause $50 \%$ growth inhibition $\left(\mathrm{EC}_{50}\right)$ values of procymidone for sensitive and resistant isolates were 0.25 and $3.60 \mu \mathrm{g} / \mathrm{ml}$, respectively. The frequency of procymidone-resistant $\left(\operatorname{Pro}^{\mathrm{R}}\right)$ isolates was $18 \%$, and the highest frequency was recorded in Jingmen. Positive crossresistance was observed for $\operatorname{Pro}^{\mathrm{R}}$ isolates to other dicarboximide fungicides but not to phenylpyrroles. Significant differences were observed for fitness parameters (i.e., mycelial growth, osmotic sensitivity, and virulence between sensitive and resistant isolates). Amino acid sequence of the Bosl gene revealed that $\operatorname{Pro}^{\mathrm{R}}$ isolates carried either point mutations at codon 365 (I365S) or a pair of point mutations at codons 369 (Q369P) and 373

(N373S). For zoxamide, the mean $\mathrm{EC}_{50}$ values for sensitive and resistant isolates were 0.22 and $5.32 \mu \mathrm{g} / \mathrm{ml}$, respectively. Approximately $14 \%$ of the isolates were found to be resistant to zoxamide, and the highest frequency of resistance was also observed in Jingmen. There was positive cross-resistance for zoxamide-resistant $\left(\mathrm{Zox}^{\mathrm{R}}\right)$ isolates to carbendazim. No significant differences were observed for fitness parameters between zoxamide-sensitive and $\mathrm{Zox}^{\mathrm{R}}$ isolates. Sequence analysis of the $\beta$-tubulin gene of Botrytis cinerea revealed two previously reported point mutations (E198A and E198K) and one new point mutation (T351I). This new mutation was detected in only those isolates which possessed the E198K but not E198A substitution. This study allows for a better understanding of the resistance development profile in Hubei Province. Results will be useful for the improvement of fungicide resistance management strategies.
\end{abstract}

Botrytis cinerea, the causal agent of gray mold, is a necrotrophic, airborne fungus and has a wide host range, including tomato (Dean et al. 2012; Kumari et al. 2014; Williamson et al. 2007). Control of $B$. cinerea is difficult due to its genetic diversity, wide host range, and survival as sclerotia, mycelia, and conidia (Braun and Sutton 1987; Diolez et al. 1995; Williamson et al. 2007). The fungus can cause preharvest losses up to $50 \%$ under favorable environmental conditions and losses may reach to $90 \%$ in severe conditions (Ellis and Grove 1982). The most efficient method to control B. cinerea is the chemical control, and about $\$ 572$ million worth of fungicides are sprayed annually to control gray mold (Dean et al. 2012).

Resistance developed after the usage of dicarboximide (DC) fungicides to control B. cinerea (Faretra and Pollastro 1991; Leroux et al. 1999). Excessive use of DC fungicides has resulted in decreased efficacy and resistance development throughout the world (Elad et al. 1992; Moorman and Lease 1992; Pappas 1997). Mutations in the Bos 1 gene are responsible for resistance to DC fungicides. Different point mutations in the Bosl gene were reported from resistant $B$. cinerea populations (Ma et al. 2007; Neumann 1992). A point mutation at codon I365 was predominant among $B$. cinerea isolates of different resistance phenotypes (Oshima et al. 2006). Point mutations always appeared in a pair in all procymidone-resistant phenotypes in commercially grown tomato (Liu et al. 2016). A combination

${ }^{\dagger}$ Corresponding author: C. X. Luo; E-mail: cxluo@mail.hzau.edu.cn

Funding: This work is supported by the Special Fund for Agro-Scientific Research in the Public Interest (numbers 201303023 and 201303025).

*The $\boldsymbol{e}$-Xtra logo stands for "electronic extra" and indicates that two supplementary tables are published online.

Accepted for publication 6 January 2018.

C 2018 The American Phytopathological Society of two point mutations (Q369P and N373S) in the Bos 1 gene was responsible for moderate resistance (Grabke et al. 2014).

Zoxamide is a benzamide fungicide having a mode of action similar to that of benzimidazoles (MBCs). With high activity against oomycetes, it can also control true fungi such as B. cinerea, Monilinia fructicola, Mycosphaerella fijiensis, Cercospora beticola, and Venturia inaequalis (Cai et al. 2016; Young and Slawecki 2001). It controls the pathogen by inhibition of tubulin polymerization and arresting nuclear division after $\beta$-subunit microtubule binding (Young and Slawecki 2001). Numerous MBC-resistant isolates have been reported for $B$. cinerea all over the world (Stehmann and Waard 1996). The most effective method to control $B$. cinerea is chemical control but $B$. cinerea frequently develops resistance toward MBC fungicides (Lorenz 1988; Smith 1988). MBCs have been used to control gray mold for decades, including thiophanate-methyl, carbendazim, and others. Zoxamide is exceptional because it not only controls true fungi but also has good activity against oomycetes (Malathrakis 1979; Smith 1988). Resistance developed soon after MBCs were introduced but the situation is different in the case of zoxamide (Bi et al. 2011, 2014; Malandrakis et al. 2011; Young et al. 2001). In many previous studies, amino acid substitution in the $\beta$-tubulin (TUB2) gene appears to be the reason for benzimidazole's resistance in pathogens such as B. cinerea, Penicillium expansum, Monilinia fructicola, Tapesia yallundae, T. acuformis, Aspergillus nidulans, and Neurospora crassa (Albertini et al. 1999; Cabañas et al. 2009; Dehne et al. 2004; Fujimura et al. 1992; Koenraadt et al. 1992; Ma et al. 2007; Orbach et al. 1986; Yarden and Katan 1993). Amino acid substitutions at codon 198 are frequently reported (Malandrakis et al. 2011). F200Y has also been reported as one more reason for high resistance to MBCs (Davidse and Ishii 1995; Yarden and Katan 1993). Low frequency of induced resistance was observed even after exposing them to UV radiations and increased zoxamide concentrations (Zhou et al. 2015). Zoxamide acts at a different $T U B 2$ site; this might be why a low frequency of zoxamide resistance was reported as compared with MBCs (Cai et al. 2015).

In this study, $B$. cinerea isolates collected from tomato were used to investigate the status of procymidone and zoxamide resistance 
development. Key objectives of this study were to (i) assess the resistance frequency of $B$. cinerea isolates to procymidone and zoxamide, (ii) elucidate the molecular mechanism of procymidone and zoxamide resistance in $B$. cinerea, and (iii) provide clues for the management of resistant $B$. cinerea populations in Hubei to avoid unexpected control failures.

\section{Materials and Methods}

Fungicides. Fungicides used in this study included procymidone (50.0\% active ingredient [a.i.], SUMILEX 50WP; Sumitomo Chemical Co., Ltd.), iprodione (50.0\% a.i.; Qingdao Nintaus Pesticides Co., Ltd.), dimethachlon (96.0\% a.i.; Wenzhou Pesticides Co., Ltd.), fludioxonil (97.0\% a.i.; Hubei Jianyuan Chemical Co., Ltd.), technical-grade zoxamide (97.5\% a.i.; Gowan Company, LLC), and technical-grade carbendazim (92.0\% a.i.; Hubei Jianyuan Chemical Co., Ltd.). Stock solutions were prepared in suitable solvents as mentioned (Supplementary Table S1) and stored in the dark at $4{ }^{\circ} \mathrm{C}$ till used.

Source of $\boldsymbol{B}$. cinerea isolates. Single-spore $B$. cinerea isolates $(n=192)$ were recovered from diseased fruit or leaves of tomato grown at different commercial greenhouses. Sampling was done during 2012 and 2013 from eight different cities in Hubei Province (Supplementary Table S2). Isolates were preserved and stored at $-20^{\circ} \mathrm{C}$ using the dried filter paper method described before (Luo et al. 2002). Isolates were identified as $B$. cinerea by a polymerase chain reaction (PCR)-based assay by using primer pair Bc-f+Bc-r (Fan et al. 2015).

Screening for resistance to fungicides. $B$. cinerea isolates were characterized as sensitive $(\mathrm{S})$ or resistant $(\mathrm{R})$ by using a discriminatory concentration (a concentration of fungicide that fully inhibits mycelial growth of the $\mathrm{S}$ isolates). According to previous studies, the discriminatory concentration was $5 \mu \mathrm{g} / \mathrm{ml}$ for both procymidone and zoxamide (Cai et al. 2015; Moyano et al. 2004). Fungicides were dissolved in their respective solvents and added to potato dextrose agar (PDA) medium. The final concentration of acetone was limited to $0.1 \%(\mathrm{vol} / \mathrm{vol})$, and the same concentrations of solvents were used as a control throughout the study. A plug $(5 \mathrm{~mm})$ of agar was taken from the borders of the 3-day-old colony grown at $23^{\circ} \mathrm{C}$ and transferred to the center of each PDA plate amended with the fungicides. After 3 days of incubation at $23^{\circ} \mathrm{C}$, the growth of colony was observed visually. For each fungicide, the isolates which were able to grow on the control as well as on amended PDA were considered resistant while isolates which failed to grow on fungicide amended PDA were considered sensitive. In total, three replications were used, and the experiment was conducted twice.

Sensitivity of $B$. cinerea mycelial growth to procymidone and zoxamide. The sensitivity of procymidone-resistant $\left(\mathrm{Pro}^{\mathrm{R}} ; n=\right.$ 35 ) and zoxamide-resistant ( $\left.\mathrm{Zox}^{\mathrm{R}} ; n=27\right)$ isolates and randomly selected procymidone-sensitive (Pros; $n=20$ ) and zoxamide-sensitive (Zox $\left.{ }^{\mathrm{S}} ; n=20\right)$ isolates was determined by evaluating the effective concentration to cause $50 \%$ growth inhibition $\left(\mathrm{EC}_{50}\right)$ values. Procymidone and zoxamide were dissolved in acetone and dimethyl sulfoxide, respectively. Solvents were used as a control, as previously described. To choose the effective concentrations for procymidone, first, a preliminary test was done to determine the range of effective concentrations (i.e., 0, 0.001, 0.01, 0.1, 1, and $10 \mu \mathrm{g} / \mathrm{ml}$ ). Based upon preliminary tests, final concentrations used for procymidone $\mathrm{EC}_{50}$ estimation were $0,0.1,0.2,0.4,0.6,0.8$, and $1 \mu \mathrm{g} / \mathrm{ml}$ and for zoxamide were $0,0.02,0.06,0.12,0.36,0.72$, and $1.4 \mu \mathrm{g} / \mathrm{ml}$. A plug $(5 \mathrm{~mm})$ of agar was taken from the borders of the 3-day-old fresh colony grown at $23^{\circ} \mathrm{C}$ and transferred to the center of PDA plates amended with a series of different fungicide concentrations. After incubation at $23^{\circ} \mathrm{C}$ for 3 days, average colony diameter was determined by measuring colony growth in two perpendicular directions, and the mycelial plug diameter $(5 \mathrm{~mm})$ was subtracted. Linear regression of percent inhibition in relation to control of mycelial growth versus $\log _{10}$ transformation of each concentration of procymidone and zoxamide was obtained. The $\mathrm{EC}_{50}$ was calculated for each isolate using linear regression in Data Processing System software (DPS, version 9.50). The $\mathrm{EC}_{50}$ values allowed the calculation of the resistance factor (the ratio of $\mathrm{EC}_{50}$ value for an $\mathrm{R}$ isolate relative to the mean $\mathrm{EC}_{50}$ value for $\mathrm{S}$ isolates
[RF value]), which shows the sensitivity level of isolates. Three replications for each isolate were used, and the experiment was repeated twice. Averages of results were calculated because there was no significant difference $(P>0.05)$ in mycelial colony diameter between the two experiments.

Cross-resistance. To determine the cross-resistance for $\operatorname{Pro}^{\mathrm{R}}$ and $\mathrm{Zox}^{\mathrm{R}}$ isolates to other fungicides, a discriminatory dose test was conducted according to previous studies (Alberoni et al. 2005; Li et al. 2003). Pro ${ }^{R}$ isolates were tested for cross-resistance with iprodione, dimethachlon, and fludioxonil but $\mathrm{Zox}^{\mathrm{R}}$ isolates were tested only with carbendazim. According to previous studies, the discriminatory concentrations were $5,1,5$, and $10 \mu \mathrm{g} / \mathrm{ml}$ for dimethachlon (Ma et al. 2009), fludioxonil (Yin et al. 2015), iprodione, and carbendazim (Bardas et al. 2010), respectively. These fungicides were dissolved in their respective solvents. Briefly, a mycelial plug $(5 \mathrm{~mm})$ from the edge of a 3-day-old colony was transferred to amended or control PDA. After 3 days of incubation at $23^{\circ} \mathrm{C}$, isolates which showed normal growth on amended PDA were considered resistant, whereas isolates which failed to grow were found to be sensitive. If resistant or sensitive phenotypes were consistent for two fungicides, crossresistance was considered in these two fungicides. In total, three replications were used and the experiment was conducted twice.

Stability of $\mathbf{R}$ isolates. Stability of $\operatorname{Pro}^{\mathrm{R}}$ and $\mathrm{Zox}^{\mathrm{R}}$ isolates was investigated. The isolates were subcultured for 10 generations on fungicide-free PDA. $\mathrm{EC}_{50}$ was determined after 1st and 10th generation.

Fitness of $\mathbf{R}$ isolates to procymidone or zoxamide. Mycelial growth, osmotic sensitivity (procymidone), virulence, and sporulation were used as parameters to test the fitness of $\mathrm{R}$ isolates to procymidone or zoxamide. Sixteen procymidone (4 S, 4 low resistant [LR], 4 moderate resistant [MR], and 4 high resistant [HR]) and 10 zoxamide (1 S and $9 \mathrm{R}$ ) isolates were selected for this experiment.

A mycelial growth test was conducted on fungicide-free PDA. Mycelial plugs were cut from the borders of a 3-day-old colony and transferred to the center of PDA plates. The colony growth diameter was measured at two perpendicular directions at $60 \mathrm{~h}$ after incubation at $23^{\circ} \mathrm{C}$ in the dark.

Osmotic sensitivity was evaluated by transferring a 5-mm plug from a 3-day-old colony to PDA plates amended with a series of different $\mathrm{NaCl}$ concentrations $(0,1,2,4,6$, and $8 \%)$. Radial colony growth was measured after 3 days of incubation at $23^{\circ} \mathrm{C}$.

Detached tomato fruit were used to evaluate sporulation fitness. Fresh fruit were washed with distilled water, then rinsed in $75 \%$ ethanol for 1 min followed by washing with distilled water, and placed on sterilized filter papers to dry. Plugs $(5 \mathrm{~mm})$ were taken from the margins of a 3-day-old colony and transferred to fruit punctured with a sterilized cork borer, as carried out in previous studies (Fan et al. 2016). The inoculated tomato fruit were incubated at $23^{\circ} \mathrm{C}$ and $100 \%$ humidity for 6 days, until sporulation occurred. Sterilized cotton buds were used to remove spores and placed inside 2-ml tubes containing distilled water with $0.05 \%$ Tween 20 to keep spores separated and prevent them from attaching to each other. Conidial suspension was then observed under a microscope.

A virulence test was conducted using fresh tomato. The fruit used were sterilized as described before. The concentration of spores was adjusted to $1 \times 10^{6} / \mathrm{ml}$ and $10 \mu l$ of spore suspension was injected into fruit using a $100-\mu 1$ syringe. Lesions area was measured with flexible plastic measuring tape after 4 days of incubation at $23^{\circ} \mathrm{C}$ and $100 \%$ humidity. Three fruit were used for each isolate. All experiments for fitness parameters were performed twice, with three replications each.

Efficacy of fungicides for control of $\boldsymbol{B}$. cinerea. Procymidone and zoxamide fungicides were sprayed at the recommended field dose (1.66 and $0.003 \mathrm{~g}$, respectively, per $500 \mathrm{ml}$ of distilled water) onto detached, surface-disinfected tomato fruit and left until dry. Plugs ( $5 \mathrm{~mm}$ in diameter) were transferred from the border of a 3-day-old colony onto the surface of fruit punctured with a sterilized cork borer (Fan et al. 2016). Lesion area was measured with flexible plastic measuring tape after 5 days of incubation at $23^{\circ} \mathrm{C}$. Three fruit were used for each isolate, and the experiment was done twice. Finally, efficacy was calculated using the following equation: disease 
control efficacy $=[$ (lesion growth of control - lesion growth of treatment)/lesion growth of control] $\times 100 \%$.

DNA extraction. For DNA extraction, six to eight plugs taken from the corner of a 2-day-old colony were transferred to $50 \mathrm{ml}$ of potato dextrose medium $(200 \mathrm{~g}$ of potato and $20 \mathrm{~g}$ of dextrose per liter of water) in a flask and then incubated in a shaker $(180 \mathrm{rpm})$ at $23^{\circ} \mathrm{C}$ for 3 days. Then, mycelia were dried and frozen. A sterilized mortar and pestle was used to grind mycelia in liquid nitrogen. Crushed tissue powder was collected in a $1.5-\mathrm{ml}$ tube, DNA was extracted using Plant DNA Mini Kit DN15 (Beijing Aid Lab Biotechnologies Co. Ltd.). After DNA confirmation on an agarose gel, the concentration was measured by a NanoDrop (DNA trace measurement) machine (NanoDrop Technologies Inc.).

Amplification and sequencing of Bos 1 and TUB2 genes. Based on the DNA sequence of gene Bosl (Gen-Bank accession number $\mathrm{AF} 396827), \mathrm{BR} 1+\mathrm{BF} 1$ and $\mathrm{BR} 2+\mathrm{BF} 2$ primer pairs were used to amplify two fragments (95 to $1,085 \mathrm{bp}$ and 981 to $1,829 \mathrm{bp}$ ) of the Bos1 gene (Table 1). A specific PCR primer pair (Bc365PM-F + Bc365PM$\mathrm{R})$ designed by using Primer Premier V5.0 was used for the remaining Pro $^{\mathrm{R}}$ isolates to amplify a fragment of the Bos 1 gene carrying the I365S single-point mutation (Table 1). The following PCR conditions were used: preheating at $94^{\circ} \mathrm{C}$ for $2 \mathrm{~min}$; followed by 32 cycles of denaturation at $94^{\circ} \mathrm{C}$ for $30 \mathrm{~s}$, annealing at $57^{\circ} \mathrm{C}$ for $\mathrm{BF} 1+\mathrm{BR} 1$ and $\mathrm{Bc} 365 \mathrm{PM}-\mathrm{F}+\mathrm{Bc} 365 \mathrm{PM}-\mathrm{R}$ or $58.3^{\circ} \mathrm{C}$ for $\mathrm{BF} 2+\mathrm{BR} 2$ for $30 \mathrm{~s}$, and extension at $72^{\circ} \mathrm{C}$ for $70 \mathrm{~s}$; with a final extension of $72^{\circ} \mathrm{C}$ for $5 \mathrm{~min}$.

For amplification of gene TUB2, primer pair P1-P2 was used to amplify the 1,765-bp fragment (Table 1). The 50- $\mu$ l PCR volume included $2 \mu \mathrm{l}$ of genomic DNA, $1 \mu \mathrm{l}$ of each primer, $21 \mu \mathrm{l}$ of doubledistilled $\mathrm{H}_{2} \mathrm{O}$, and $25 \mu$ l of $2 \times$ Taq PCR Mix (AidLab Biotech). PCR conditions consisted of preheating at $94^{\circ} \mathrm{C}$ for $5 \mathrm{~min}$; followed by 35 cycles of denaturation at $94^{\circ} \mathrm{C}$ for $1 \mathrm{~min}$, annealing at $63^{\circ} \mathrm{C}$ for $1 \mathrm{~min}$, and extension at $72^{\circ} \mathrm{C}$ for $90 \mathrm{~s}$; with a final extension of $72^{\circ} \mathrm{C}$ for $10 \mathrm{~min}$ and a holding temperature of $4^{\circ} \mathrm{C}$.

Amplified PCR products were separated by electrophoresis on 1.5\% agarose gels in Tris-acetate (Oshima et al. 2006) buffer and photographed after staining with ethidium bromide. The fragment was purified using a UNIQ gel extraction kit (EasyPure Quick Gel Extraction Kit; TransGen Biotech Co.), then sequenced by Wuhan Tianyi Huiyuan Biotechnology Co., Ltd. BioEdit Sequence Alignment Editor version 7.1.3.0 and ClustalW were used for the sequence analysis.

\section{Results}

Frequency distribution of tomato $\mathbf{R}$ isolates. Of the 192 tomato isolates, $18 \%$ (35 isolates) and 14\% (27 isolates) of the total isolates collected from the eight locations in Hubei were resistant to procymidone and zoxamide, respectively. Isolates from Jingmen showed the highest resistance frequencies (i.e., $56 \%$ for procymidone and $68 \%$ for zoxamide) for both fungicides. On the other hand, no R isolates were detected for procymidone in Xiangyang and zoxamide in Jingzhou and Shiyan (Fig. 1A and B).

Sensitivity of $B$. cinerea to procymidone and zoxamide. The $\mathrm{EC}_{50}$ values for procymidone and zoxamide for $\mathrm{S}$ tomato isolates ranged from 0.08 to $0.67 \mu \mathrm{g} / \mathrm{ml}$, with a mean of $0.25 \mu \mathrm{g} / \mathrm{ml}$, and from 0.03 to $0.65 \mu \mathrm{g} / \mathrm{ml}$, with a mean of $0.22 \mu \mathrm{g} / \mathrm{ml}$, respectively (Fig. 2). The $\mathrm{EC}_{50}$ values for $35 \mathrm{Pro}^{\mathrm{R}}$ isolates ranged from 1.27 to $9.36 \mu \mathrm{g} / \mathrm{ml}$, with a mean of $3.60 \mu \mathrm{g} / \mathrm{ml}$. The $\mathrm{EC}_{50}$ values for $27 \mathrm{Zox}^{\mathrm{R}}$ isolate ranged from 1.97 to $18.02 \mu \mathrm{g} / \mathrm{ml}$, with a mean of $5.32 \mu \mathrm{g} / \mathrm{ml}$. Pro ${ }^{\mathrm{R}}$ and $\mathrm{Zox}^{\mathrm{R}}$ isolates showed a wide range of resistance, with $\mathrm{RF}$ values of 4.93 to 36.28 , with a mean of 13.82 , and 4 to 78.67 , with a mean of 19.31, respectively (Table 2).

Different levels of resistance among $\operatorname{Pro}^{\mathrm{R}}$ isolates were observed. Because different levels of resistance have been found associated with specific mutations in previous studies, the Pro ${ }^{R}$ phenotypes were categorized as LR, MR, and HR based on a previous study (Grabke et al. 2014). Among $35 \mathrm{R}$ isolates, 8 isolates were LR, 21 isolates were MR, and 6 isolates were HR.

Cross resistance. All Pro ${ }^{\mathrm{R}}$ isolates showed positive cross resistances with DC fungicides (i.e., iprodione and dimethachlon) whereas they were sensitive to a phenylpyrrole (PP) fungicide (i.e., fludioxonil).

Table 1. Primers used in this study

\begin{tabular}{|c|c|c|c|}
\hline Prime name & Sequence $\left(5^{\prime}-3^{\prime}\right)$ & Location in gene & Reference \\
\hline $\mathrm{Bc}-\mathrm{f}$ (forward) & CAGGAAACACTTTTGGGGATA & Amplify 327-bp Bos 1 gene fragment of Botrytis cinerea & Fan et al. 2015 \\
\hline Bc-r (reverse) & GAGGGACAAGAAAATCGACTAA & $\ldots$ & $\ldots$ \\
\hline BF1 (forward) & TACCGATCGAAAAACCCAAC & Amplify 990-bp $(95-1,085)$ Bos 1 gene fragment of $B$. cinerea & Ma et al. 2007 \\
\hline BR1 (reverse) & TGGGCTGGTCTCTCAATCTT & $\ldots$ & $\ldots$ \\
\hline BF2 (forward) & CAACGTTATGGCACAAAATCTCA & Amplify 848-bp $(981-1,829)$ Bos 1 gene fragment of $B$. cinerea & $\ldots$ \\
\hline BR2 (reverse) & AAGTTTCTGGCCATGGTGTTCA & $\ldots$ & $\ldots$ \\
\hline P1 (forward) & ATGCGTGAGATTGTATGTATTTC & Amplify 1,765 -bp $\beta$-tubulin gene fragment of $B$. cinerea & Liu et al. 2010 \\
\hline P2 (reverse) & CTATTCCTCGCCCTCAATTG & $\ldots$ & $\ldots$ \\
\hline $\mathrm{Bc} 365 \mathrm{PM}-\mathrm{F}$ (forward) & GAAAGCGAAGGCGTCCAG & $\begin{array}{l}\text { Allele-specific polymerase chain reaction primers to detect } \\
\text { I365S point mutation in Bos } 1 \text { gene }\end{array}$ & This study \\
\hline Bc365PM-R (reverse) & GTCTCCCTTTGCGACAGC & $\ldots$ & $\ldots$ \\
\hline
\end{tabular}
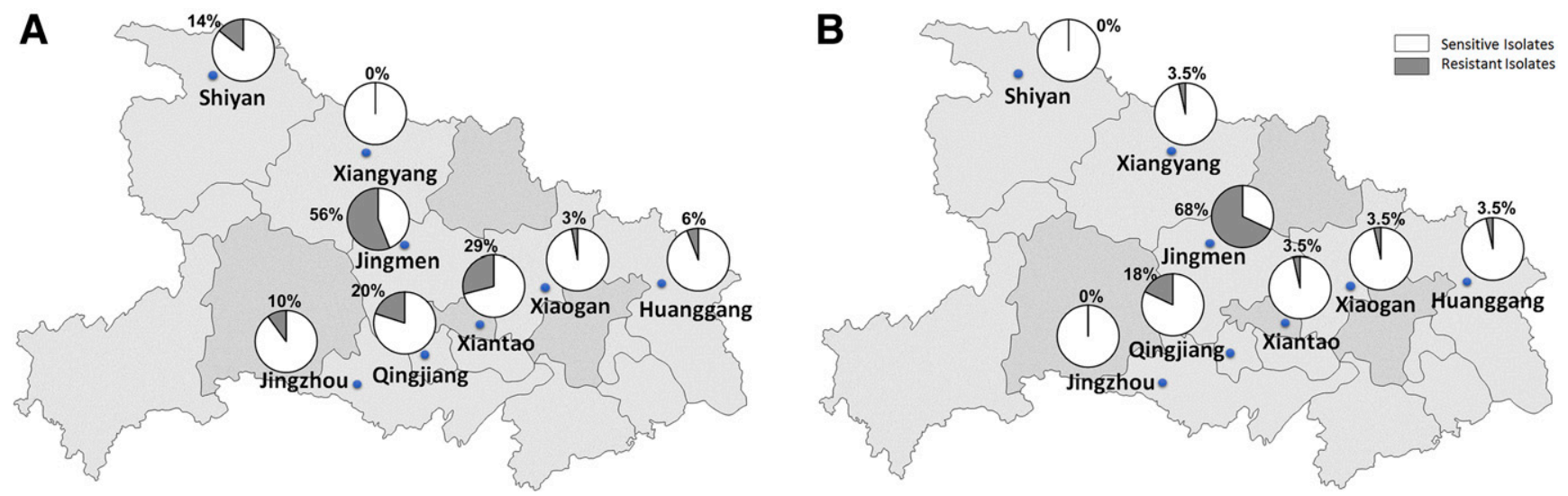

Fig. 1. Frequency distribution of $\mathbf{A}$, procymidone-resistant and $\mathbf{B}$, zoxamide-resistant isolates of Botrytis cinerea collected from tomato greenhouses in eight locations of Hubei Province, China. 
In the case of zoxamide, all $\mathrm{R}$ isolates showed positive cross resistances with a MBC fungicide (i.e., carbendazim) (Table 3).

Stability of $\mathbf{R}$ isolates. After 10 successive generations on fungicide-free PDA medium, mean $\mathrm{EC}_{50}$ values of $\mathrm{Pro}^{\mathrm{R}}$ and $\mathrm{Zox}^{\mathrm{R}}$ isolates were compared between the 1 st and 10th generation. The variation of the mean $\mathrm{EC}_{50}$ values was not significantly different (procymidone, $P=0.16$ and zoxamide, $P=0.17$ ). Some isolates increased in resistance while others decreased, but collectively the isolates maintained the level of resistance (Table 4).

Fitness of $\mathbf{R}$ isolates. Selected $\operatorname{Pro}^{\mathrm{R}}(\mathrm{S}, \mathrm{LR}, \mathrm{MR}$, and HR) and $\mathrm{Zox}^{\mathrm{R}}$ isolates were evaluated for fitness parameters such as mycelial growth test, osmotic sensitivity, virulence, and sporulation. Significant differences were observed between $\operatorname{Pro}^{\mathrm{S}}$ and $\mathrm{Pro}^{\mathrm{R}}$ isolates regarding mycelial growth $(P=0.002)$, osmotic sensitivity $(P=0.003)$, and virulence $(P=0.024)$ but not in sporulation $(P=0.867)$. Zoxamide isolates showed no significant difference for all fitness parameters. In brief, significant differences were observed for mycelial growth between $\operatorname{Pro}^{\mathrm{S}}$ and $\operatorname{Pro}^{\mathrm{R}}$ isolates $(P=0.002)$ (Table 4). In the osmotic sensitivity test, Pro $^{\mathrm{R}}$ isolates showed slower and decreased growth on $\mathrm{NaCl}$-amended PDA plates $(P=0.003)$. The percentage of inhibition of mycelial radial growth (PIMG) on PDA plates amended with $8 \%$ $\mathrm{NaCl}$ was the most apparent for $\mathrm{R}$ isolates compared with $\mathrm{NaCl}$-free medium. Among R isolates, T400 showed the highest percentage of inhibition of PIMG compared with others. The results demonstrated that the $\mathrm{R}$ isolates were relatively more sensitive to osmotic stress compared with S isolates (Table 4). Virulence on tomato fruit, measured as lesion size, was also assessed between Pro $^{\mathrm{R}}$ and Pro ${ }^{\mathrm{S}}$ isolates and $\mathrm{Zox}^{\mathrm{R}}$ and $\mathrm{Zox}^{\mathrm{S}}$ isolates. There were significant differences observed between mean lesion size of $\mathrm{S}$ and $\mathrm{R}$ isolates from procymidone $(P=$ $0.024)$ and there was also significant difference found for virulence among different levels of procymidone resistance isolates (LR, MR, and HR) $(P=0.059)$. No significant difference was observed for virulence of $\mathrm{Zox}^{\mathrm{S}}$ and $\mathrm{Zox}^{\mathrm{R}}$ isolates. Upon comparison of sporulation of zoxamide isolates, no significant differences were found between $\mathrm{S}$ and $\mathrm{R}$ isolates $(P=1.000)$ (Table 4$)$.

Control efficacy for $\mathbf{R}$ isolates. $\operatorname{Pro}^{\mathrm{R}}$ and $\mathrm{Zox}^{\mathrm{R}}$ isolates were subjected to an in vivo sensitivity assay for fungicides to assess the
Table 2. Sensitivity of Botrytis cinerea-resistant and -sensitive isolates to procymidone and zoxamide

\begin{tabular}{|c|c|c|c|c|}
\hline Phenotypew $^{w}$ & Isolate & Resistance $^{\mathrm{x}}$ & $\mathrm{EC}_{50}\left(\mu \mathrm{g} \mathrm{ml}^{-1}\right)^{\mathrm{y}}$ & RF value \\
\hline $\operatorname{Pro}^{\mathrm{S}}$ & $\mathrm{T} 227$ & $S$ & 0.13 & $\ldots$ \\
\hline $\operatorname{Pro}^{\mathrm{S}}$ & $\mathrm{T} 401$ & S & 0.15 & $\ldots$ \\
\hline $\operatorname{Pro}^{\mathrm{S}}$ & $\mathrm{T} 402$ & S & 0.17 & $\ldots$ \\
\hline $\operatorname{Pro}^{\mathrm{S}}$ & $\mathrm{T} 429$ & S & 0.17 & $\ldots$ \\
\hline $\operatorname{Pro}^{\mathrm{R}}$ & QJ4 & LR & 0.98 & 3.83 \\
\hline $\operatorname{Pro}^{R}$ & T312 & LR & 2.37 & 9.19 \\
\hline $\operatorname{Pro}^{\mathrm{R}}$ & T405 & LR & 1.27 & 4.93 \\
\hline $\operatorname{Pro}^{\mathrm{R}}$ & T521 & LR & 1.43 & 5.55 \\
\hline $\operatorname{Pro}^{\mathrm{R}}$ & $\mathrm{T} 79$ & MR & 3.61 & 14.03 \\
\hline $\operatorname{Pro}^{\mathrm{R}}$ & $\mathrm{T} 381$ & MR & 3.65 & 14.18 \\
\hline $\operatorname{Pro}^{\mathrm{R}}$ & T399 & MR & 4.13 & 16.04 \\
\hline $\operatorname{Pro}^{\mathrm{R}}$ & $\mathrm{T} 400$ & MR & 4.15 & 16.10 \\
\hline $\operatorname{Pro}^{\mathrm{R}}$ & $\mathrm{T} 177$ & HR & 9.36 & 36.28 \\
\hline $\operatorname{Pro}^{\mathrm{R}}$ & T380 & HR & 5.41 & 20.98 \\
\hline $\operatorname{Pro}^{\mathrm{R}}$ & T387 & HR & 5.04 & 19.56 \\
\hline $\operatorname{Pro}^{\mathrm{R}}$ & $\mathrm{T} 403$ & HR & 6.92 & 26.83 \\
\hline $\mathrm{Zox}^{\mathrm{S}}$ & T507 & S & 0.16 & $\ldots$ \\
\hline Zox $^{\mathrm{R}}$ & T295 & $\mathrm{R}$ & 3.32 & 14.50 \\
\hline Zox $^{\mathrm{R}}$ & QJ40 & $\mathrm{R}$ & 0.92 & 4.03 \\
\hline $\operatorname{Zox}^{\mathrm{R}}$ & $\mathrm{T} 121$ & $\mathrm{R}$ & 2.42 & 10.57 \\
\hline$Z_{o x}{ }^{R}$ & $\mathrm{~T} 135$ & $\mathrm{R}$ & 2.52 & 11.03 \\
\hline$Z_{o x}{ }^{R}$ & T388 & $\mathrm{R}$ & 4.72 & 20.62 \\
\hline$Z_{o x}{ }^{R}$ & T396 & $\mathrm{R}$ & 2.85 & 12.46 \\
\hline Zox $^{\mathrm{R}}$ & $\mathrm{T} 400$ & $\mathrm{R}$ & 10.83 & 47.31 \\
\hline Zox $^{\mathrm{R}}$ & $\mathrm{T} 403$ & $\mathrm{R}$ & 1.50 & 6.53 \\
\hline Zox $^{\mathrm{R}}$ & $\mathrm{T} 405$ & $\mathrm{R}$ & 18.01 & 78.66 \\
\hline
\end{tabular}

${ }^{\mathrm{w}} \mathrm{Pro}^{\mathrm{S}}=$ procymidone sensitive, $\operatorname{Pro}^{\mathrm{R}}=$ procymidone resistant, $\mathrm{Zox}^{\mathrm{S}}=$ zoxamide sensitive, and $\mathrm{Zox}^{\mathrm{R}}=$ zoxamide resistant.

${ }^{x}$ Resistance levels of isolates. LR, MR, and HR represent low, moderate, and high resistance, respectively; $\mathrm{S}=$ sensitive and $\mathrm{R}=$ resistant.

y $\mathrm{EC}_{50}=$ fungicide concentration resulting in inhibition of $50 \%$ mycelial growth.

$\mathrm{z} \mathrm{RF}=$ resistance factor, calculated by dividing the $\mathrm{EC}_{50}$ value of the resistant isolate by the mean $\mathrm{EC}_{50}$ value of the sensitive isolates.
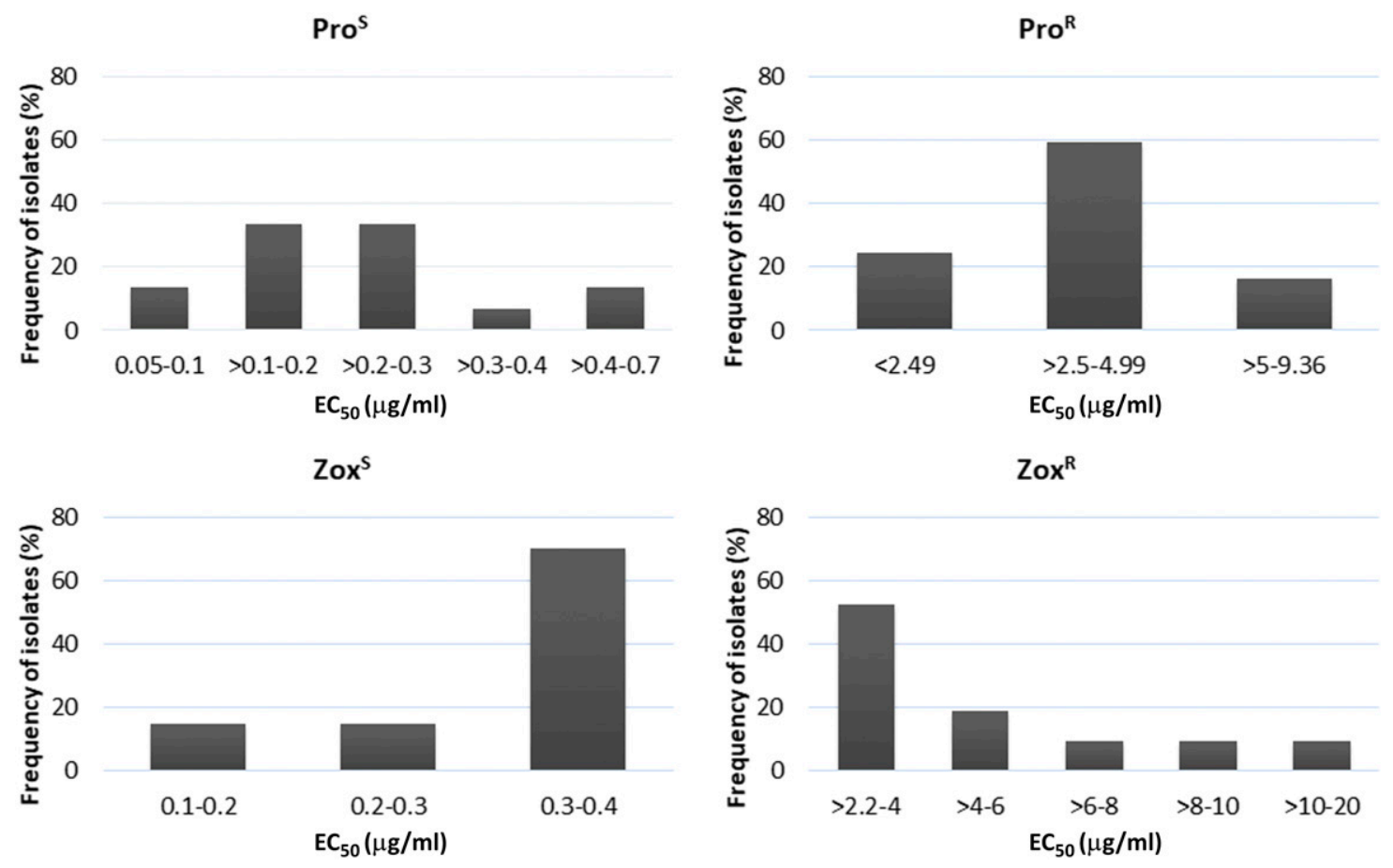

Fig. 2. Frequency distribution of effective concentration to cause $50 \%$ growth inhibition $\left(E C_{50}\right)$ values $(\mu \mathrm{g} / \mathrm{ml})$ for isolates of Botrytis cinerea sensitive and resistant to procymidone and zoxamide collected from tomato greenhouses in eight locations of Hubei Province, China. Pro ${ }^{S}$ and Pro ${ }^{R}$ represent procymidone-sensitive and -resistant isolates and Zox ${ }^{S}$ and $\mathrm{Zox}^{\mathrm{R}}$ represent zoxamide-sensitive and -resistant isolates. 
control efficacy on detached tomato fruit. Control efficacy for Pro $\mathrm{S}$ and $\mathrm{Zox}^{\mathrm{S}}$ isolates was $100 \%$ because all of them failed to grow or cause lesions on fruit. For Pro $^{\mathrm{R}}$ isolates, control efficacy was observed between 4.99 and $24.9 \%$, and the lowest control efficacy was observed as $4.99 \%$ for isolate $\mathrm{T} 177$. In the case of $\mathrm{Zox}^{\mathrm{R}}$ isolates, least control efficacy observed was $4.4 \%$ for isolate T405 (Table 4). The results showed that there was a significant difference $(P=$ 0.0002 ) for control efficacy between $S$ and $\mathrm{R}$ isolates of both procymidone and zoxamide fungicides, and the tested fungicides could not control the $\mathrm{R}$ isolates successfully, suggesting the high risk of management of these resistant $B$. cinerea isolates in practice.

Molecular characterization of Bos1 and TUB2 genes. Gene Bos 1 from one S, four LR, four MR, and three HR isolates to procymidone was sequenced. Sequence comparison of $S$ and $R$ isolates (4 LR and $3 \mathrm{HR}$ ) revealed a point mutation at codon 365 resulting in the substitution of isoleusine to serine (I365S) in R isolates. A pair of point mutations was detected in the sequence of four MR isolates. The first point mutation was observed at codon position 369 and the second point mutation occurred at codon 373, resulting in replacement of glutamine to proline (Q369P) and asparagine to serine (N373S), respectively. Amplification of a specific fragment of Bos1 gene with a primer pair (Bc365PM-F + Bc365PM-R) detected a I365S point mutation in an additional six Pro $^{R}$ isolates; two were LR while four were MR isolates.

Gene TUB2 was sequenced from nine $\mathrm{Zox}^{\mathrm{R}}$ isolates along with one $\mathrm{Zox}^{\mathrm{S}}$ isolate. Sequence comparison of eight $\mathrm{Zox}^{\mathrm{R}}$ isolates revealed a substitution at position 198 from GAG to AAG, resulting in replacement of amino acid from glutamic acid to lysine (E198K). The sequence of the remaining one $\mathrm{R}$ isolate revealed the substitution from GAG to GCG, resulting in replacement of amino acid at the same position from glutamic acid to alanine (E198A). Interestingly, all eight isolates with the E198K point mutation also possessed another point mutation which has not been previously reported. That is the substitution at amino acid position 351 from threonine to isoleusine (T351I).
For confirmation, an additional nine $\mathrm{Zox}^{\mathrm{S}}$ isolates were sequenced, and none of them harbored this newly discovered point mutation but two isolates were found to possess the E198A point mutation. Both point mutations (E198K + T351I) appeared together in all selected isolates, while the new point mutation never combined with the E198A mutation (Fig. 3A and B).

\section{Discussion}

Fungicide resistance is a common problem occurring as a result of the extensive use of a fungicide to control a specific pathogen in the same area for several seasons. In Hubei Province, $B$. cinerea is a major factor limiting the production of soft fruit such as tomato. Recently, $B$. cinerea populations collected from different locations in Hubei Province developed resistance to several fungicides from different chemical groups, indicating that there is a need to design resistance management strategies to control the pathogen in Hubei Province (Fan et al. 2016, 2017). In this study, 18 and $14 \%$ isolates were found to be resistant to fungicides procymidone and zoxamide, respectively, which confirmed our hypothesis that fungicide resistance is becoming a serious problem in Hubei Province. Resistance to various classes of fungicides, including DC, PP, $\mathrm{MBC}$, and benzamides, were previously reported not only in China but also around the world (Cai et al. 2016; Faretra and Pollastro 1991; Grabke et al. 2014; Korolev et al. 2011; Leroux et al. 2002; Liu et al. 2016; Moyano et al. 2004; Oshima et al. 2006; PetsikosPanayotarou et al. 2003; Sun et al. 2010; Sergeeva et al. 2002).

The frequency of $B$. cinerea isolates resistant to DC was found 18 , 20 , and $23 \%$ at different locations in North and South Carolina (Grabke et al. 2014). The frequency of $B$. cinerea isolates resistant to procymidone in Jiangsu and Henan Provinces was recorded as 53 and $85 \%$, respectively (Liu et al. 2016; Sun et al. 2010). Our results showed less frequency of resistant $B$. cinerea isolates as compared with these previous reports but we expect that it will increase with the extensive usage of the fungicides in the future.

Table 3. Cross-resistance test for procymidone and zoxamide with other relative fungicides in Botrytis cinerea isolates ${ }^{\mathrm{w}}$

\begin{tabular}{|c|c|c|c|c|c|c|}
\hline \multirow[b]{2}{*}{ Phenotype $^{y}$} & \multirow[b]{2}{*}{ Isolate } & \multirow[b]{2}{*}{ Resistance $^{\mathrm{z}}$} & \multicolumn{4}{|c|}{ Sensitivity $^{x}$} \\
\hline & & & Carbendazim & Dimethachlon & Iprodione & Fludioxonil \\
\hline $\mathrm{Pro}^{\mathrm{S}}$ & $\mathrm{T} 227$ & $\mathrm{~S}$ & $\ldots$ & $S$ & $S$ & $S$ \\
\hline $\mathrm{Pro}^{\mathrm{S}}$ & T401 & $\mathrm{S}$ & $\ldots$ & $\mathrm{S}$ & $\mathrm{S}$ & $\mathrm{S}$ \\
\hline $\operatorname{Pro}^{S}$ & $\mathrm{~T} 402$ & S & $\ldots$ & $\mathrm{S}$ & $\mathrm{S}$ & S \\
\hline $\operatorname{Pro}^{S}$ & $\mathrm{~T} 429$ & S & $\ldots$ & $\mathrm{S}$ & $\mathrm{S}$ & $S$ \\
\hline $\operatorname{Pro}^{\mathrm{R}}$ & QJ4 & LR & $\ldots$ & $\mathrm{R}$ & $\mathrm{R}$ & S \\
\hline $\operatorname{Pro}^{R}$ & $\mathrm{~T} 312$ & LR & $\begin{array}{l}\cdots \\
\cdots\end{array}$ & $\mathrm{R}$ & $\mathrm{R}$ & S \\
\hline $\operatorname{Pro}^{\mathrm{R}}$ & $\mathrm{T} 405$ & LR & $\ldots$ & $\mathrm{R}$ & $\mathrm{R}$ & S \\
\hline $\operatorname{Pro}^{\mathrm{R}}$ & $\mathrm{T} 521$ & LR & $\ldots$ & $\mathrm{R}$ & $\mathrm{R}$ & $S$ \\
\hline $\operatorname{Pro}^{\mathrm{R}}$ & $\mathrm{T} 79$ & MR & $\ldots$ & $\mathrm{R}$ & $\mathrm{R}$ & S \\
\hline $\operatorname{Pro}^{R}$ & $\mathrm{~T} 381$ & MR & $\ldots$ & $\mathrm{R}$ & $\mathrm{R}$ & S \\
\hline $\operatorname{Pro}^{\mathrm{R}}$ & T399 & MR & $\cdots$ & $\mathrm{R}$ & $\mathrm{R}$ & $S$ \\
\hline $\operatorname{Pro}^{\mathrm{R}}$ & $\mathrm{T} 400$ & MR & $\ldots$ & $\mathrm{R}$ & $\mathrm{R}$ & $S$ \\
\hline $\operatorname{Pro}^{\mathrm{R}}$ & $\mathrm{T} 177$ & $\mathrm{HR}$ & $\ldots$ & $\mathrm{R}$ & $\mathrm{R}$ & $S$ \\
\hline $\operatorname{Pro}^{\mathrm{R}}$ & Т380 & HR & $\ldots$ & $\mathrm{R}$ & $\mathrm{R}$ & $S$ \\
\hline $\operatorname{Pro}^{\mathrm{R}}$ & $\mathrm{T} 387$ & $\mathrm{HR}$ & $\ldots$ & $\mathrm{R}$ & $\mathrm{R}$ & S \\
\hline $\operatorname{Pro}^{\mathrm{R}}$ & $\mathrm{T} 403$ & $\mathrm{HR}$ & $\ldots$ & $\mathrm{R}$ & $\mathrm{R}$ & S \\
\hline$Z_{o x}{ }^{s}$ & $\mathrm{~T} 507$ & $\mathrm{~S}$ & $\mathrm{~s}$ & $\ldots$ & $\ldots$ & $\ldots$ \\
\hline Zox $^{R}$ & $\mathrm{~T} 295$ & $\mathrm{R}$ & $\mathrm{R}$ & $\cdots$ & $\cdots$ & $\cdots$ \\
\hline Zox $^{R}$ & QJ40 & $\mathrm{R}$ & $\mathrm{R}$ & $\begin{array}{l}\cdots \\
\cdots\end{array}$ & $\begin{array}{l}\cdots \\
\cdots\end{array}$ & $\begin{array}{l}\cdots \\
\cdots\end{array}$ \\
\hline Zox $^{R}$ & $\mathrm{~T} 121$ & $\mathrm{R}$ & $\mathrm{R}$ & $\ldots$ & $\ldots$ & $\ldots$ \\
\hline$Z_{0 x}{ }^{R}$ & $\mathrm{~T} 135$ & $\mathrm{R}$ & $\mathrm{R}$ & $\ldots$ & $\ldots$ & $\ldots$ \\
\hline$Z_{0 x^{R}}$ & T388 & $\mathrm{R}$ & $\mathrm{R}$ & $\ldots$ & $\ldots$ & $\ldots$ \\
\hline$Z_{0 x}{ }^{R}$ & T396 & $\mathrm{R}$ & $\mathrm{R}$ & $\cdots$ & $\cdots$ & $\ldots$ \\
\hline$Z_{0 x}{ }^{R}$ & $\mathrm{~T} 400$ & $\mathrm{R}$ & $\mathrm{R}$ & $\begin{array}{l}\cdots \\
\ldots\end{array}$ & $\cdots$ & $\begin{array}{l}\cdots \\
\ldots\end{array}$ \\
\hline Zox $^{R}$ & $\mathrm{~T} 403$ & $\mathrm{R}$ & $\mathrm{R}$ & $\begin{array}{l}\cdots \\
\ldots\end{array}$ & $\begin{array}{l}\cdots \\
\cdots\end{array}$ & $\ldots$ \\
\hline Zox $^{\mathrm{R}}$ & $\mathrm{T} 405$ & $\mathrm{R}$ & $\mathrm{R}$ & $\ldots$ & $\ldots$ & $\ldots$ \\
\hline
\end{tabular}

${ }^{\mathrm{w}}$ Discriminatory doses (a concentration of fungicide that fully inhibits mycelial growth of the sensitive isolates) used for sensitivity were $10,5,5$, and $1 \mu \mathrm{g} / \mathrm{ml}$ for carbendazim, dimethachlon, iprodione, and fludioxonil, respectively.

${ }^{x} \mathrm{~S}=$ sensitive and $\mathrm{R}=$ resistant, based on carbendazim sensitivity to zoxamide-resistant $\left(\right.$ Zox $\left.^{\mathrm{R}}\right)$ isolates and dimethachlon, fludioxonil, and iprodione sensitivity to procymidone-resistant $\left(\mathrm{Pro}^{\mathrm{R}}\right)$ isolates.

${ }^{\text {y }} \mathrm{Pro}^{\mathrm{S}}=$ procymidone sensitive and $\mathrm{Zox}^{\mathrm{S}}=$ zoxamide sensitive.

${ }^{\mathrm{z}}$ Resistance levels of procymidone-resistant isolates. LR, MR, and HR represent low, moderate, and high resistance, respectively. 
Previous reports of fitness studies also reveal that there was a significant difference for DC but no significant difference between benzamide-sensitive and resistant field isolates of $B$. cinerea, which is in line with our findings (Liu et al. 2016; Moyano et al. 2004; Sun et al. 2010; Zhang et al. 2007). Fitness assessment suggested a high risk for the use of zoxamide because the $\mathrm{R}$ isolates have comparable contestability with $\mathrm{S}$ isolates in the field. Although DC-resistant isolates showed a certain fitness penalty, considering that the highest recommended rate of procymidone could not control them efficiently, the risk to use DC alone is still high to control $B$. cinerea isolates in the field. In our studies, $B$. cinerea isolates resistant to procymidone (DC) were sensitive to fludioxonil (PP), which is consistent with previous studies that reported no cross resistance of DC to PP for field isolates (Faretra and Pollastro 1993; Fillinger et al. 2012; Hilber et al. 1995; Leroux et al. 1999; Vignutelli et al. 2002; Ziogas and Kalamarakis 2001). This result indicated that fludioxonil is a good compound to control Pro $^{\mathrm{R}}$ B. cinerea populations.

Resistance to DC fungicide is related to mutations in the Bos 1 gene (Ma et al. 2007). B. cinerea isolates with various levels of resistance, whether they have a low, intermediate, or high range of $\mathrm{EC}_{50}$, all possess one to several point mutations; and, among them, the I365 codon mutation is predominant (Oshima et al. 2006). I365 N/S alone in the Bos1 gene was responsible for low resistance (Grabke et al. 2014). Point mutation variations at single codon I365S/N/R of the Bosl gene were responsible for DC low resistance reported from France, England, Israel, Japan, New Zealand, Italy, Switzerland, and the United States (Cui et al. 2004; De Miccolis Angelini et al. 2007; Leroux et al. 2002; $\mathrm{Ma}$ et al. 2007; Oshima et al. 2002). Our results match with these reported studies of Bos 1 gene analysis. I365S point mutation was detected in LR isolates but, at the same time, this mutation was also detected in MR and HR isolates. The presence of this single point mutation in HR isolates may also be associated with multidrug efflux, as previously described (Grabke et al. 2014). Point mutations Q369P and N373S were always found together in $\operatorname{Pro}^{\mathrm{R}}$ isolates and these results were consistent with the findings in Henan Province (Liu et al. 2016). It has been reported that a combination of two point mutations (e.g., Q369P and N373S) in the Bos1 gene was responsible for moderate resistance (Grabke et al. 2014). Similarly, we detected the pair of point mutations Q369P and N373S from MR isolates. It should be noted that four MR isolates also possessed the I365S point mutation, suggesting that the MR phenotype is not associated with specific point mutation and different mechanisms should be involved.

Table 4. Fitness components, control efficacy, and stability of procymidone- or zoxamide-resistant Botrytis cinerea isolates from tomato, with sensitive isolates used as control ${ }^{\mathrm{r}}$

\begin{tabular}{|c|c|c|c|c|c|c|c|c|c|}
\hline \multirow[b]{2}{*}{ Type $^{t}$} & \multirow[b]{2}{*}{ Isolate } & \multirow[b]{2}{*}{ Levelu $^{\text {u }}$} & \multirow[b]{2}{*}{ Growthv } & \multirow[b]{2}{*}{ PIMG (\%)w } & \multirow[b]{2}{*}{$\operatorname{Vir}(\mathbf{c m})^{x}$} & \multirow[b]{2}{*}{ Spor $\left(\times 10^{6} / \mathrm{cm}^{2}\right)^{y}$} & \multirow[b]{2}{*}{ Efficacy $^{\mathbf{z}}$} & \multicolumn{2}{|c|}{$\begin{array}{c}\text { Resistance stability } \\
\text { EC }_{50}\left(\mu \mathrm{g} \mathrm{ml}^{-1}\right)^{\mathrm{s}} \\
\end{array}$} \\
\hline & & & & & & & & 1st & 10th \\
\hline $\mathrm{Pro}^{\mathrm{S}}$ & T227 & $\mathrm{S}$ & 6.97 & 98.44 & 2.20 & 6.91 & 100 & $\ldots$ & $\ldots$ \\
\hline $\mathrm{Pro}^{\mathrm{S}}$ & $\mathrm{T} 401$ & S & 6.51 & 96.13 & 2.77 & 4.06 & 100 & $\ldots$ & $\ldots$ \\
\hline $\mathrm{Pro}^{\mathrm{S}}$ & $\mathrm{T} 402$ & S & 6.51 & 83.61 & 2.48 & 5.56 & 100 & $\ldots$ & $\ldots$ \\
\hline $\operatorname{Pro}^{\mathrm{S}}$ & $\mathrm{T} 429$ & S & 7.00 & 95.63 & 2.84 & 5.26 & 100 & $\ldots$ & $\ldots$ \\
\hline Mean & $\ldots$ & S & $6.75 \pm 0.26 \mathrm{~A}$ & $93.46 \pm 3.42 \mathrm{C}$ & $2.57 \pm 0.09 \mathrm{C}$ & $5.45 \pm 0.33 \mathrm{~A}$ & $100 \pm 0.00 \mathrm{~A}$ & $\ldots$ & $\ldots$ \\
\hline $\mathrm{Pro}^{\mathrm{R}}$ & QJ4 & LR & 5.30 & 104.23 & 2.37 & 7.75 & 8.80 & 0.98 & 1.12 \\
\hline $\operatorname{Pro}^{R}$ & T312 & LR & 5.38 & 102.24 & 2.84 & 6.50 & 24.90 & 2.37 & 2.31 \\
\hline $\operatorname{Pro}^{\mathrm{R}}$ & $\mathrm{T} 405$ & LR & 6.12 & 108.08 & 3.01 & 6.50 & 11.73 & 1.27 & 2.24 \\
\hline $\operatorname{Pro}^{R}$ & $\mathrm{~T} 521$ & LR & 5.75 & 116.14 & 2.75 & 7.83 & 14.70 & 1.43 & 2.39 \\
\hline Mean & $\ldots$ & LR & $5.64 \pm 0.18 \mathrm{C}$ & $107.68 \pm 4.84 \mathrm{~B}$ & $2.75 \pm 0.13 \mathrm{BC}$ & $7.15 \pm 0.46 \mathrm{~A}$ & $15.03 \pm 2.47 \mathrm{~B}$ & $1.51 \pm 0.19 \mathrm{~A}$ & $2.01 \pm 0.27 \mathrm{~A}$ \\
\hline $\operatorname{Pro}^{\mathrm{R}}$ & $\mathrm{T} 79$ & MR & 5.78 & 114.01 & 2.77 & 5.80 & 9.02 & 3.61 & 4.73 \\
\hline $\operatorname{Pro}^{\mathrm{R}}$ & T381 & MR & 5.60 & 109.06 & 3.13 & 6.84 & 7.70 & 3.65 & 2.88 \\
\hline $\operatorname{Pro}^{R}$ & T399 & MR & 6.20 & 125.08 & 2.87 & 5.00 & 8.21 & 4.13 & 3.86 \\
\hline $\operatorname{Pro}^{\mathrm{R}}$ & $\mathrm{T} 400$ & MR & 5.92 & 134.58 & 2.91 & 5.13 & 9.91 & 4.15 & 4.53 \\
\hline Mean & $\ldots$ & MR & $5.92 \pm 0.09 \mathrm{BC}$ & $120.68 \pm 6.14 \mathrm{~A}$ & $2.92 \pm 0.06 \mathrm{~A} \mathrm{~B}$ & $5.69 \pm 0.75 \mathrm{~A}$ & $8.71 \pm 2.19 \mathrm{BC}$ & $3.88 \pm 0.28 \mathrm{~A}$ & $4.00 \pm 0.41 \mathrm{~A}$ \\
\hline $\operatorname{Pro}^{\mathrm{R}}$ & $\mathrm{T} 177$ & HR & 5.81 & 114.59 & 3.08 & 6.75 & 4.99 & 9.36 & 7.55 \\
\hline $\operatorname{Pro}^{\mathrm{R}}$ & T380 & HR & 6.32 & 104.13 & 3.03 & 6.01 & 5.94 & 5.41 & 5.19 \\
\hline $\operatorname{Pro}^{\mathrm{R}}$ & T387 & HR & 6.63 & 104.47 & 2.91 & 8.86 & 13.80 & 5.04 & 4.99 \\
\hline $\operatorname{Pro}^{R}$ & $\mathrm{~T} 403$ & $\mathrm{HR}$ & 6.48 & 109.46 & 3.15 & 4.60 & 6.72 & 6.92 & 5.29 \\
\hline Mean & $\ldots$ & $\mathrm{HR}$ & $6.31 \pm 0.13 \mathrm{~B}$ & $108.17 \pm 4.34 \mathrm{~B}$ & $3.04 \pm 0.09 \mathrm{~A}$ & $6.55 \pm 1.07 \mathrm{~A}$ & $7.86 \pm 1.55 \mathrm{C}$ & $6.68 \pm 0.46 \mathrm{~A}$ & $5.75 \pm 0.32 \mathrm{~A}$ \\
\hline $\mathrm{Zox}^{\mathrm{s}}$ & $\mathrm{T} 507$ & $S$ & $7.25 \pm 0.21 \mathrm{~A}$ & $\ldots$ & $5.17 \pm 0.22 \mathrm{~A}$ & $5.20 \pm 0.58 \mathrm{~A}$ & $100 \pm 0 \mathrm{~A}$ & $\ldots$ & $\ldots$ \\
\hline$Z_{0 x}{ }^{R}$ & $\mathrm{~T} 295$ & $\mathrm{R}$ & 7.25 & $\ldots$ & 4.26 & 5.90 & 10.37 & 3.32 & 3.41 \\
\hline Zox $^{\mathrm{R}}$ & QJ40 & $\mathrm{R}$ & 6.32 & $\ldots$ & 5.14 & 7.360 & 13.09 & 0.92 & 1.22 \\
\hline Zox $^{\mathrm{R}}$ & $\mathrm{T} 121$ & $\mathrm{R}$ & 6.37 & $\ldots$ & 4.11 & 4.50 & 7.61 & 2.42 & 2.19 \\
\hline $\mathrm{Zox}^{\mathrm{R}}$ & $\mathrm{T} 135$ & $\mathrm{R}$ & 6.43 & $\ldots$ & 5.31 & 4.60 & 6.52 & 2.52 & 2.64 \\
\hline Zox $^{\mathrm{R}}$ & T388 & $\mathrm{R}$ & 6.79 & $\ldots$ & 5.32 & 5.80 & 12.41 & 4.72 & 4.57 \\
\hline Zox $^{\mathrm{R}}$ & T396 & $\mathrm{R}$ & 6.57 & $\ldots$ & 4.48 & 3.90 & 15.49 & 2.85 & 3.10 \\
\hline Zox $^{\mathrm{R}}$ & $\mathrm{T} 400$ & $\mathrm{R}$ & 6.01 & $\ldots$ & 4.60 & 5.10 & 6.81 & 10.83 & 9.72 \\
\hline$Z_{0 x}{ }^{R}$ & $\mathrm{~T} 403$ & $\mathrm{R}$ & 6.26 & $\ldots$ & 4.49 & 6.20 & 8.55 & 1.50 & 1.33 \\
\hline $\mathrm{Zox}^{\mathrm{R}}$ & $\mathrm{T} 405$ & $\mathrm{R}$ & 7.16 & $\ldots$ & 5.26 & 3.50 & 4.40 & 18.01 & 19.75 \\
\hline Mean & $\ldots$ & $\mathrm{R}$ & $6.58 \pm 0.12 \mathrm{~A}$ & $\ldots$ & $4.78 \pm 0.13 \mathrm{~A}$ & $5.23 \pm 0.33 \mathrm{~A}$ & $9.47 \pm 0.64 \mathrm{~B}$ & $5.23 \pm 0.17 \mathrm{~A}$ & $5.32 \pm 0.24 \mathrm{~A}$ \\
\hline
\end{tabular}

${ }^{\mathrm{r}}$ Means were indicated as averages \pm standard deviation; sensitive and the corresponding resistant isolates within a column followed by the same letter did not show significant differences according to the least significant difference test $(P=0.05)$.

${ }^{\mathrm{s}} \mathrm{EC}_{50}=$ mean effective concentration to cause $50 \%$ growth inhibition. Stability of procymidone-resistant $\left(\operatorname{Pro}^{\mathrm{R}}\right)$ and zoxamide-resistant $\left(\right.$ Zox $\left.{ }^{\mathrm{R}}\right)$ isolates after 10 consecutive transfers on fungicide-free medium (1st and 10th transfer). Means were compared between 1st and 10th transfers of each group.

${ }^{t}$ Phenotypes (Type); $\operatorname{Pro}^{\mathrm{S}}=$ procymidone sensitive and $\mathrm{Zox}^{\mathrm{S}}=$ zoxamide sensitive.

u Resistance levels of isolates. LR, MR, and HR represent low, moderate, and high resistance, respectively; $\mathrm{S}=$ sensitive and $\mathrm{R}=$ resistant.

${ }^{v}$ Mycelium growth was shown as colony diameter (in centimeters) at $60 \mathrm{~h}$ under $23^{\circ} \mathrm{C}$.

w Osmotic sensitivity $8 \%$. Percentage of inhibition of mycelial radial growth (PIMG) was calculated using the formula PIMG $=[(\mathrm{C}-\mathrm{N}) /(\mathrm{C}-5)] \times 100$, where $\mathrm{C}$ is the colony diameter of the nontreatment control and $\mathrm{N}$ is that of the sodium chloride treatment.

$x$ Virulence (Vir) was shown as the diameter of lesion size $(\mathrm{cm})$ at 3 days under $23^{\circ} \mathrm{C}$.

y Sporulation (Spor). Mean number $\left(\times 10^{6}\right)$ of conidia per square centimeter.

${ }^{\mathrm{z}}$ Control efficacy was expressed as the percentage of the mean diameter of the control minus the mean diameter of the treatment divided by the mean diameter of the control. 
Zoxamide is a benzamide fungicide having a mode of action similar to MBCs. It not only has good activity against oomycetes but also can control true fungi such as B. cinerea (Cai et al. 2016; Young and Slawecki 2001). Soon after MBCs were introduced, resistance started to develop, but this has not been observed for zoxamide (Bi et al. 2011, 2014; Malandrakis et al. 2011; Young et al. 2001). Mostly, amino acid substitution in the TUB2 gene appears to be the reason of benzimidazole's resistance in pathogens such as B. cinerea, P. expansum, M. fructicola, T. acuformis, T. yallundae, A. nidulans, $V$. inaequalis, and $N$. crassa (Albertini et al. 1999; Cabañas et al. 2009; Dehne et al. 2004; Fujimura et al. 1992; Koenraadt et al. 1992; Ma et al. 2007; Orbach et al. 1986; Yarden and Katan 1993). The risk of resistance development for zoxamide is very low whereas MBCs are at high risk for several pathogens (Albertini et al. 1999; Cabañas et al. 2009; Krämer and Schirmer 2007; Malandrakis et al. 2011; Sun et al. 2010; Smith 1988). In oomycetes, zoxamide lab-induced resistance is also rarely reported except in Pythium sylvaticum and P. capsici (Bi et al. 2011; Martinez et al. 2003). The difference between zoxamide and MBCs is that the zoxamide is used against diploid oomycetes whereas MBCs are against haploid stages of true fungi (Bi et al. 2014). Low risk for zoxamide resistance development was observed among eight $B$. cinereasensitive isolates; only one was mutated after many transfers, and the resulting mutants showed a fitness penalty. Molecular docking analysis revealed the formation of two strong hydrogen bonds between a side-chain of carbendazim and E198 but zoxamide did not form a direct interaction; this could be why mutations at this codon have less effect on the sensitivity of zoxamide compared with carbendazim. Authors suggested that the difference in the binding pocket of zoxamide and the target sites acting on TUB2 makes it different from MBCs (Cai et al. 2015). In Liaoning Province and Inner Mongolia, $84 \%$ of $B$. cinerea isolates were found to be resistant to carbendazim (Cai et al. 2015). A high frequency (63.63\%) of graymold-resistant isolates to carbendazim was also detected in Hubei Province (Fan et al. 2017). In our study, the frequency of Zox ${ }^{\mathrm{R}}$ isolates was found to be just $14 \%$, which is low and consistent with the previous studies. Such results suggest that zoxamide could be used as a candidate to manage the resistance to MBCs in $B$. cinerea.

Amino acid substitutions at codons 198 and 200 of the TUB2 gene are frequently reported (Malandrakis et al. 2011). It has previously been noted that the replacement of amino acids from glutamic acid at codon 198 to alanine, valine, glycine, or lysine $(\mathrm{A} / \mathrm{V} / \mathrm{G} / \mathrm{K})$ is related to a high resistance level to carbendazim (Albertini et al. 1999; Cabañas et al. 2009; Fujimura et al. 1992; Koenraadt et al. 1992; Malandrakis et al. 2011). For carbendazim, the formation of two strong hydrogen bonds at codon 198 of the TUB2 gene indicates

\begin{tabular}{|c|c|}
\hline & (198) \\
\hline $\mathrm{S}$ & EPYNATLSVHQLVENSDETFCIDNEALYDICMRTLKLSNPSYGDLNHLVSAVMSGVTTCL \\
\hline T121 & EPYNATLSVHQLVENSDKTFCIDNEALYDICMRTLKLSNPSYGDLNHLVSAVMSGVTTCL \\
\hline T135 & EPYNATLSVHQLVENSDKTFCIDNEALYDICMRTLKLSNPSYGDLNHLVSAVMSGVTTCL \\
\hline T295 & EPYNATLSVHQLVENSDATFCIDNEALYDICMRTLKLSNPSYGDLNHLVSAVMSGVTT \\
\hline T405 & EPYNATLSVHQLVENSDKTFCIDNEALYDICMRTLKLSNPSYGDLNHLVSAVMSGVT \\
\hline T388 & EPYNATLSVHQLVENSDKTFCIDNEALYDICMRTLKLSNPSYGDLNHLVSAVMSGVT \\
\hline T396 & EPYNATLSVHQLVENSDKTFCIDNEALYDICMRTLKLSNPSYGDLNHLVSAVMSGVTTCL \\
\hline T400 & EPYNATLSVHQLVENSDKTFCIDNEALYDICMRTLKLSNPSYGDLNHLVSAVMSGVTTCL \\
\hline T403 & EPYNATLSVHQLVENSDKTFCIDNEALYDICMRTLKLSNPSYGDLNHLVSAVMSGVTT \\
\hline QJ40 & 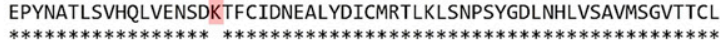 \\
\hline
\end{tabular}

\begin{tabular}{|c|c|}
\hline & (351) \\
\hline $\mathrm{s}$ & AASDFRNGRYLTCSAIFRGKVSMKEVEDQMRNVQNKNSSYFVEWIPNNVQTALCSIP \\
\hline t121 & AASDFRNGRYLTCSAIFRGKVSMKEVEDQMRNVQNKNSSYFVEWIPNNVQIALCSIPF \\
\hline T135 & AASDFRNGRYLTCSAIFRGKVSMKEVEDQMRNVQNKNSSYFVEWIPNNVQIALCSIP \\
\hline T295 & AASDFRNGRYLTCSAIFRGKVSMKEVEDQMRNVQNKNSSYFVEWIPNNVQTALCSIF \\
\hline t405 & AASDFRNGRYLTCSAIFRGKVSMKEVEDQMRNVQNKNSSYFVEWIPNNVQIALCSIP \\
\hline T388 & AASDFRNGRYLTCSAIFRGKVSMKEVEDQMRNVQNKNSSYFVEWIPNNVQIALCSIP \\
\hline t396 & AASDFRNGRYLTCSAIFRGKVSMKEVEDQMRNVQNKNSSYFVEWIPNNVQIALCSIP \\
\hline t400 & AASDFRNGRYLTCSAIFRGKVSMKEVEDQMRNVQNKNSSYFVEWIPNNVQIALCSIPPRG \\
\hline T403 & AASDFRNGRYLTCSAIFRGKVSMKEVEDQMRNVQNKNSSYFVEWIPNNVQIALCSIPPRG \\
\hline QJ40 & 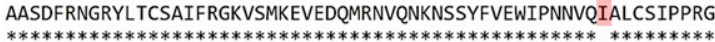 \\
\hline
\end{tabular}

Fig. 3. Amino acid sequence alignment of Botrytis cinerea $\beta$-tubulin with mutation variations at positions 198 and 351 . S represents sensitive isolate. that it has a major role in resistance development (Cai et al. 2015). The most predominant point mutation found in $B$. cinerea isolates resistant to carbendazim was E198V (Fan et al. 2017). Point mutation E198V is not associated with zoxamide resistance (Cai et al. 2015; Dehne et al. 2004; Malandrakis et al. 2011). In our study, we were unable to detect E198V point mutation among the Zox ${ }^{\mathrm{R}}$ isolates, indicating that the zoxamide is a good candidate to control MBC-resistant isolates with point mutation E198V. Mutation E198A of TUB2 was detected in the majority of resistant $B$. cinerea isolates and has been responsible for high resistance to MBCs (Banno et al. 2008; Li et al. 2014). Increased sensitivity to zoxamide was observed due to E198A mutation (Cai et al. 2015; Dehne et al. 2004; Malandrakis et al. 2011). In our study, the E198A mutation was detected in one Zox $^{\mathrm{R}}$ isolate and two $\mathrm{Zox}^{\mathrm{S}}$ isolates, suggesting that another mechanism instead of E198A conferred the resistance to zoxamide and the zoxamide could be used to control MBC-resistant isolates with point mutation E198A. In the previous study, point mutation M233I was suggested to be the determinant of zoxamide resistance (Cai et al. 2015). In our study, a new point mutation (T351I) was detected from eight of nine tested isolates. Molecular docking analysis of the TUB2 gene with zoxamide and MBCs showed that even zoxamide was a component of binding pocket but had no direct interaction with E198. Codon E198 is strongly associated with MBC resistance (Cai et al. 2015). Interestingly, the newly detected point mutation T351I was only found in association with E198K in ox $^{\mathrm{R}}$ isolates. Because E198K has no direct interaction with zoxamide, it is suggested that T351I might confer the resistance in these isolates. To the best of our knowledge, it is the first report of the T351I mutation in field isolates of $B$. cinerea.

Conclusively, the risk of fungicide development in $B$. cinerea is a serious problem for tomato growers in Hubei Province, China. According to the results of current study, we cannot rely on the use of DC fungicides separately to control this destructive disease. Integrated disease management is the strategy we should focus on, in addition to the use of biological control and agricultural practices. Using fungicides such as fludioxonil with a low risk of resistance development should be very important to manage the destructive $B$. cinerea. Zoxamide could also be used to control some MBC-resistant populations such as those with mutation E198V or E198A of TUB2.

\section{Literature Cited}

Alberoni, G., Collina, M., Pancaldi, D., and Brunelli, A. 2005. Resistance to dicarboximide fungicides in Stemphylium vesicarium of Italian pear orchards. Eur. J. Plant Pathol. 113:211-219.

Albertini, C., Gredt, M., and Leroux, P. 1999. Mutations of the $\beta$-tubulin gene associated with different phenotypes of benzimidazole resistance in the cereal eyespot fungi Tapesia yallundae and Tapesia acuformis. Pestic. Biochem. Physiol. 64:17-31.

Banno, S., Fukumori, F., Ichiishi, A., Okada, K., Uekusa, H., Kimura, M., and Fujimura, M. 2008. Genotyping of benzimidazole-resistant and dicarboximideresistant mutations in Botrytis cinerea using real-time polymerase chain reaction assays. Phytopathology 98:397-404.

Bardas, G. A., Veloukas, T., Koutita, O., and Karaoglanidis, G. S. 2010. Multiple resistance of Botrytis cinerea from kiwifruit to SDHIs, QoIs and fungicides of other chemical groups. Pest Manage. Sci. 66:967-973.

Bi, Y., Chen, L., Cai, M., Zhu, S., Pang, Z., and Liu, X. 2014. Two non-target recessive genes confer resistance to the anti-oomycete microtubule inhibitor zoxamide in Phytophthora capsici. PLoS One 9:e89336.

Bi, Y., Cui, X., Lu, X., Cai, M., Liu, X., and Hao, J. J. 2011. Baseline sensitivity of natural population and resistance of mutants in Phytophthora capsici to zoxamide. Phytopathology 101:1104-1111.

Braun, P., and Sutton, J. 1987. Inoculum sources of Botrytis cinerea in fruit rot of strawberries in Ontario. Can. J. Plant Pathol. 9:1-5.

Cabañas, R., Castellá, G., Abarca, M. L., Bragulat, M. R., and Cabañes, F. J. 2009. Thiabendazole resistance and mutations in the $\beta$-tubulin gene of Penicillium expansum strains isolated from apples and pears with blue mold decay. FEMS Microbiol. Lett. 297:189-195.

Cai, M., Lin, D., Chen, L., Bi, Y., Xiao, L., and Liu, X. L. 2015. M233I mutation in the $\beta$-tubulin of Botrytis cinerea confers resistance to zoxamide. Sci. Rep. 5: Article 16881.

Cai, M., Miao, J., Song, X., Lin, D., Bi, Y., Chen, L., Liu, X., and Tyler, B. M. 2016. C239S mutation in the $\beta$-tubulin of Phytophthora sojae confers resistance to zoxamide. Front. Microbiol. 7:762.

Cui, W., Beever, R. E., Parkes, S. L., and Templeton, M. D. 2004. Evolution of an osmosensing histidine kinase in field strains of Botryotinia fuckeliana (Botrytis cinerea) in response to dicarboximide fungicide usage. Phytopathology 94 $1129-1135$ 
Davidse, L., and Ishii, H. 1995. Biochemical and molecular aspects of the mechanisms of action of benzimidazoles, N-phenylcarbamates and N-phenylformamidoximes and the mechanisms of resistance to these compounds in fungi. Pages 305-322 in: Modern Selective Fungicides. H. Lyr, ed. Gustav Fischer Verlag, Jena, Germany.

De Miccolis Angelini, R., Rotolo, C., Habib, W., Pollastro, S., and Faretra, F. 2007. Single nucleotide polymorphisms (SNPs) in Botryotinia fuckeliana genes involved in fungicide resistance. Pages 21-26 in: Abstr. Book 14th Int. Botrytis Symp. Cape Town, South Africa.

Dean, R., Van Kan, J. A., Pretorius, Z. A., Hammond-Kosack, K. E., Di Pietro, A., Spanu, P. D., Rudd, J. J., Dickman, M., Kahmann, R., Ellis, J., and Foster, G. D. 2012. The top 10 fungal pathogens in molecular plant pathology. Mol. Plant Pathol. 13:414-430.

Dehne, H., Gisi, U., Kuck, K., Russell, P., and Lyr, H. 2004. Modern fungicides and antifungal compounds IV. In: 14th Int. Reinhardsbrunn Symp. Br. Crop Prot. Counc. Friedrichroda, Thuringia, Germany.

Diolez, A., Marches, F., Fortini, D., and Brygoo, Y. 1995. Boty, a long-terminalrepeat retroelement in the phytopathogenic fungus Botrytis cinerea. Appl. Environ. Microbiol. 61:103-108.

Elad, Y., Yunis, H., and Katan, T. 1992. Multiple fungicide resistance to benzimidazoles, dicarboximides and diethofencarb in field isolates of Botrytis cinerea in Israel. Plant Pathol. 41:41-46.

Ellis, M., and Grove, G. 1982. Fruit Rots Cause Losses in Ohio Strawberries (Botrytis cinerea, Phytophthora cactorum). Ohio Agricultural Research and Development Center, Wooster, Ohio.

Fan, F., Hamada, M., Li, N., Li, G. Q., and Luo, C. X. 2017. Multiple fungicide resistance in Botrytis cinerea from greenhouse strawberries in Hubei Province, China. Plant Dis. 101:601-606.

Fan, F., Li, N., Li, G. Q., and Luo, C. X. 2016. Occurrence of fungicide resistance in Botrytis cinerea from greenhouse tomato in Hubei Province, China. Plant Dis. 100:2414-2421.

Fan, X., Zhang, J., Yang, L., Wu, M., Chen, W., and Li, G. 2015. Development of PCR-based assays for detecting and differentiating three species of Botrytis infecting broad bean. Plant Dis. 99:691-698.

Faretra, F., and Pollastro, S. 1991. Genetic basis of resistance to benzimidazole and dicarboximide fungicides in Botryotinia fuckeliana (Botrytis cinerea). Mycol. Res. 95:943-951.

Faretra, F., and Pollastro, S. 1993. Genetics of sexual compatibility and resistance to benzimidazole and dicarboximide fungicides in isolates of Botryotinia fuckeliana (Botrytis cinerea) from nine countries. Plant Pathol. 42:48-57.

Fillinger, S., Ajouz, S., Nicot, P. C., Leroux, P., and Bardin, M. 2012. Functional and structural comparison of pyrrolnitrin-and iprodione-induced modifications in the class III histidine-kinase Bos1 of Botrytis cinerea. PLoS One 7:e42520.

Fujimura, M., Kamakura, T., Inoue, H., Inoue, S., and Yamaguchi, I. 1992. Sensitivity of Neurospora crassa to benzimidazoles and N-phenylcarbamates: Effect of amino acid substitutions at position 198 in $\beta$-tubulin. Pestic. Biochem. Physiol. 44:165-173.

Grabke, A., Fernández-Ortuño, D., Amiri, A., Li, X., Peres, N. A., Smith, P., and Schnabel, G. 2014. Characterization of iprodione resistance in Botrytis cinerea from strawberry and blackberry. Phytopathology 104:396-402.

Hilber, U., Schwinn, F., and Schüepp, H. 1995. Comparative resistance patterns of fludioxonil and vinclozolin in Botryotinia fuckeliana. J. Phytopathol. 143:423-428.

Koenraadt, H., Somerville, S. C., and Jones, A. 1992. Characterization of mutations in the beta-tubulin gene of benomyl-resistant field strains of Venturia inaequalis and other plant pathogenic fungi. Phytopathology 82:1348-1354.

Korolev, K. S., Xavier, J. B., Nelson, D. R., and Foster, K. R. 2011. A quantitative test of population genetics using spatiogenetic patterns in bacterial colonies. Am. Nat. 178:538-552

Krämer, W., and Schirmer, U., eds. 2007. Modern Crop Protection Compounds. WILEY-VCH Verlag GmbH \& Co. KGaA, Weinheim, Germany.

Kumari, S., Tayal, P., Sharma, E., and Kapoor, R. 2014. Analyses of genetic and pathogenic variability among Botrytis cinerea isolates. Microbiol. Res. 169: 862-872.

Leroux, P., Chapeland, F., Desbrosses, D., and Gredt, M. 1999. Patterns of crossresistance to fungicides in Botryotinia fuckeliana (Botrytis cinerea) isolates from French vineyards. Crop Prot. 18:687-697.

Leroux, P., Fritz, R., Debieu, D., Albertini, C., Lanen, C., Bach, J., Gredt, M., and Chapeland, F. 2002. Mechanisms of resistance to fungicides in field strains of Botrytis cinerea. Pest Manage. Sci. 58:876-888.

Li, H. X., Lu, Y. J., Zhou, M. G., and Wang, X. F. 2003. Mutation in $\beta$-tubulin of Sclerotinia sclerotiorum conferring resistance to carbendazim in rapeseed field isolates. Chin. J. Oil Crop Sci. 25:56-60.

Li, X., Fernández-Ortuño, D., Chen, S., Grabke, A., Luo, C.-X., Bridges, W. C., and Schnabel, G. 2014. Location-specific fungicide resistance profiles and evidence for stepwise accumulation of resistance in Botrytis cinerea. Plant Dis. 98:1066-1074

Liu, S., Che, Z., and Chen, G. 2016. Multiple-fungicide resistance to carbendazim, diethofencarb, procymidone, and pyrimethanil in field isolates of Botrytis cinerea from tomato in Henan Province, China. Crop Prot. 84:56-61.

Liu, S. M., Chen, Y., Yu, J. J., Chen, C. J., Wang, J. X., and Zhou, M. G. 2010. Transfer of the beta-tubulin gene of Botrytis cinerea with resistance to carbendazim into Fusarium graminearum. Pest Manag. Sci. 66:482-489.
Lorenz, G. 1988. Dicarboximide fungicides: History of resistance development and monitoring methods. Pages 45-51 in: Fungicide Resistance in North America. IV Dicarboximide Fungicides. C. J. Delp, B. R. Delp, T. M. Fortii, H. V. Morton, and C. M. Smith, eds. American Phytopathological Society, St. Paul, MN.

Luo, C.-X., Hanamura, H., Sezaki, H., Kusaba, M., and Yaegashi, H. 2002 Relationship between avirulence genes of the same family in rice blast fungus Magnaporthe grisea. J. Gen. Plant Pathol. 68:300-306.

Ma, H.-X., Chen, Y., Wang, J.-X., Yu, W.-Y., Tang, Z.-H., Chen, C.-J., and Zhou, M.-G. 2009. Activity of carbendazim, dimethachlon, iprodione, procymidone and boscalid against Sclerotinia stem rot in Jiangsu Province of China. Phytoparasitica 37:421-429.

Ma, Z., Yan, L., Luo, Y., and Michailides, T. J. 2007. Sequence variation in the two-component histidine kinase gene of Botrytis cinerea associated with resistance to dicarboximide fungicides. Pestic. Biochem. Physiol. 88:300-306.

Malandrakis, A., Markoglou, A., and Ziogas, B. 2011. Molecular characterization of benzimidazole-resistant $B$. cinerea field isolates with reduced or enhanced sensitivity to zoxamide and diethofencarb. Pestic. Biochem. Physiol. 99:118-124.

Malathrakis, N. 1979. Studies on gray mold (Botrytis cinerea) of vegetables grown under plastics. Phytopathol. Mediterr. 19:70.

Martinez, F., Blancard, D., Lecomte, P., Levis, C., Dubos, B., and Fermaud, M. 2003. Phenotypic differences between vacuma and transposa subpopulations of Botrytis cinerea. Eur. J. Plant Pathol. 109:479-488.

Moorman, G. W., and Lease, R. J. 1992. Benzimidazole- and dicarboximide-resistant Botrytis cinerea from Pennsylvania greenhouses. Plant Dis. 76:477-480.

Moyano, C., Gómez, V., and Melgarejo, P. 2004. Resistance to pyrimethanil and other fungicides in Botrytis cinerea populations collected on vegetable crops in Spain. J. Phytopathol. 152:484-490.

Neumann, G. L. 1992. Pyrimethanil: A new fungicide. In: Brighton Crop Prot Conf. Pests Dis.

Orbach, M. J., Porro, E. B., and Yanofsky, C. 1986. Cloning and characterization of the gene for beta-tubulin from a benomyl-resistant mutant of Neurospora crassa and its use as a dominant selectable marker. Mol. Cell. Biol. 6:2452-2461.

Oshima, M., Banno, S., Okada, K., Takeuchi, T., Kimura, M., Ichiishi, A. Yamaguchi, I., and Fujimura, M. 2006. Survey of mutations of a histidine kinase gene $\mathrm{BcOS} 1$ in dicarboximide-resistant field isolates of Botrytis cinerea. J. Gen. Plant Pathol. 72:65-73.

Oshima, M., Fujimura, M., Banno, S., Hashimoto, C., Motoyama, T., Ichiishi, A., and Yamaguchi, I. 2002. A point mutation in the two-component histidine kinase BcOS-1 gene confers dicarboximide resistance in field isolates of Botrytis cinerea. Phytopathology 92:75-80.

Pappas, A. C. 1997. Evolution of fungicide resistance in Botrytis cinerea in protected crops in Greece. Crop Prot. 16:257-263.

Petsikos-Panayotarou, N., Markellou, E., Kalamarakis, A. E., Kyriakopoulou, D., and Malathrakis, N. E. 2003. In vitro and in vivo activity of cyprodinil and pyrimethanil on Botrytis cinerea isolates resistant to other botryticides and selection for resistance to pyrimethanil in a greenhouse population in Greece. Eur. J. Plant Pathol. 109:173-182.

Sergeeva, V., Nair, N. G., Verdanega, J. R., Shen, C., Barchia, I., and SpoonerHart, R. 2002. First report of anilinopyrimidine-resistant phenotypes in Botrytis cinerea on grapevines in Australia. Australas. Plant Pathol. 31:299-300.

Smith, C. M. 1988. History of benzimidazole use and resistance. Pages 23-24 in: Fungicide Resistance in North America. C. J. Delp, ed. American Phytopathological Society, St. Paul, MN.

Stehmann, C., and Waard, M. A. D. 1996. Sensitivity of populations of Botrytis cinerea to triazoles, benomyl and vinclozolin. Eur. J. Plant Pathol. 102:171-180.

Sun, H. Y., Wang, H. C., Yu, C., Li, H. X., Chen, C. J., and Zhou, M. G. 2010 Multiple resistance of Botrytis cinerea from vegetable crops to carbendazim, diethofencarb, procymidone, and pyrimethanil in China. Plant Dis. 94:551-556.

Vignutelli, A., Hilber-Bodmer, M., and Hilber, U. W. 2002. Genetic analysis of resistance to the phenylpyrrole fludioxonil and the dicarboximide vinclozolin in Botryotinia fuckeliana (Botrytis cinerea). Mycol. Res. 106:329-335.

Williamson, B., Tudzynski, B., Tudzynski, P., and Kan, J. A. L. V. 2007. Botrytis cinerea: The cause of grey mould disease. Mol. Plant Pathol. 8:561-580.

Yarden, O., and Katan, T. 1993. Mutations leading to substitutions at amino acids 198 and 200 of beta-tubulin that correlate with benomyl-resistance phenotypes of field strains of Botrytis cinerea. Phytopathology 83:1478-1483.

Yin, D., Chen, X., Hamada, M. S., Yu, M., Yin, Y., and Ma, Z. 2015. Multiple resistance to QoIs and other classes of fungicides in Botrytis cinerea populations from strawberry in Zhejiang Province, China. Eur. J. Plant Pathol. 141:169-177.

Young, D. H., and Slawecki, R. A. 2001. Mode of action of zoxamide (RH-7281), a new oomycete fungicide. Pestic. Biochem. Physiol. 69:100-111.

Young, D. H., Spiewak, S. L., and Slawecki, R. A. 2001. Laboratory studies to assess the risk of development of resistance to zoxamide. Pest Manage. Sci. 57:1081-1087.

Zhang, H., Wang, L., Dong, Y., Jiang, S., Cao, J., and Meng, R. 2007. Postharvest biological control of gray mold decay of strawberry with Rhodotorula glutinis. Biol. Control 40:287-292.

Zhou, Y., Chen, L., Hu, J., Duan, H., Lin, D., Liu, P., Meng, Q., Li, B., Si, N., and Liu, C. 2015. Resistance mechanisms and molecular docking studies of four novel QoI fungicides in Peronophythora litchii. Sci. Rep. 5:17466.

Ziogas, B., and Kalamarakis, A. 2001. Phenylpyrrole fungicides: Mitotic instability in Aspergillus nidulans and resistance in Botrytis cinerea. J. Phytopathol. 149:301-308. 